\title{
Hubungan Peran Orang Tua Dengan Kejadian Karies Gigi Pada Anak Pra Sekolah Di Taman Kanak-Kanak (TK) Nurul Kamka, Kecamatan Binjai Timur
}

\author{
Taruli Rohana Sinaga $^{1 *}$, Elsarika Damanik, Christina Roos Etty ${ }^{1}$, Sarindah Sihaloho ${ }^{1}$ \\ Universitas Sari Mutiara Indonesia \\ Taruli71@yahoo.co.id
}

\begin{abstract}
ABSTRAK
Karies gigi merupakan kerusakan jaringan keras gigi yang disebabkan oleh bakteri, mikroorganisme, dan saliva. Karies gigi bisa terbentuk karena adanya sisa-sisa makanan yang menempel pada gigi, dampaknya gigi menjadi keropos, berlubang bahkan patah. Tujuan penelitian ini adalah mengetahui hubungan peran orang tua dengan kejadian karies gigi pada anak pra sekolah di taman kanank-kanak (TK) Nurul Kamka, Kecamatan Binjai Timur. Metode penelitian yang digunakan yaitu deskriptif korelasi dengan pendekatancross sectional. Populasi dalam penelitian ini seluruh ibu yang anaknya mengalami karies gigi dengan teknik pengambilan sampel yaitu total sampling sehingga jumlah sampel pada penelitian ini yaitu 30 orang. Penelitian ini menggunakan uji statistik chi square. Hasil penelitian menunjukkan bahwa orang tua berperan cukup dengan frekuensi 50\% dan anak mengalami karies gigi berat dengan frekuensi $60 \%$ dimana nilai $p=0,012 ; p<0,05$. Dari hasil penelitian ini dapat dilihat bahwa ada hubungan peran orang tua dengan kejadian karies gigi pada anak pra sekolah di taman kanak-kanak (TK) Nurul Kamka, Kecamatan Binjai Timur. Sehingga diharapkan orang tua dapat lebih memperhatikan dan memelihara kesehatan gigi pada anak agar kejadian karies gigi pada anak pra sekolah dapat berkurang.
\end{abstract}

\section{Kata kunci: Peran Orang Tua, Karies Gigi, Anak Pra Sekolah}

\section{ABSTRACT}

Dental caries is dental hard tissue damage which caused by bacteria, microorganism and saliva. It is formed by leftovers that stick to teeth and caused calcification of teeth. The effect are dental porous, perforated and broken dental. The aim of this research is to know the correlation between parent role and pre-school children dental carries in Nurul Kamka Kindergarten, Binjai Timur District. The method was correlative description. By using croos sectional approach. The population were all of parents who had dental carries children.the sample was total sampling wchich amount was 30 people. This research used chi-square statistic setting. It showed that parents hard enough role $50 \%$ and pre-school children dental caries $60 \%$ in $p=0,012 ; p=0,05$. The result showed that there was parents role in dental caries of pre-school children, of Nurul Kamka Kindergarten, Binjai Timur District. Parents should more attent and maintain the dental health of children as dental carries of pre school children will decrease.

Keywords:Parents Role, Dental Caries, Pre-School Children 


\section{PENDAHULUAN}

Karies gigi dapat dialami oleh setiap orang dan dapat timbul pada satu permukaan gigi atau lebih, serta dapat meluas kebagian yang lebih dalam dari gigi, misalnya dari email ke dentin atau ke pulpa (Rasinta Tarigan, 2017). Karies gigi merupakan penyakit kronis pada anak-anak yang sering terjadi dan tingkatnya 5 kali lebih tinggi dari asma. Karies merupakan penyebab patologi primer atas penanggalan gigi pada anak-anak (Indah Irma Z \& S. Ayu Intan, 2017).

Karies gigi terdapat diseluruh dunia tanpa memandang umur, bangsa ataupun keadaan ekonomi. Organisasi Kesehatan Dunia (WHO) tahun 2016 mengatakan angka kejadian karies pada anak masih sebesar 60-90\%. Menurut penelitian di Negara-negara Eropa, Amerika, dan Asia, termasuk Indonesia, ternyata $80-90 \%$ anak di bawah usia 18 tahun terserang karies gigi (Rasinta Tarigan, 2017).

Hasil penelitian Firmansyah (2017) menunjukkan bahwa peran orang tua mempunyai hubungan yang signifikan dengan kejadian karies pada anak prasekolah di TK Karta Rini Sleman, Yogyakarta. Orang tua kurang memiliki peran untuk menjaga kebersihan gigi pada anaknya dengan cara menganjurkan anak mereka untuk menggosok gigi 3 kali sehari, mengurangi mengkonsumsi makanan yang mengandung gula, dan memeriksakan ke dokter gigi minimal 6 bulan sekali. Angka Prevalensi karies gigi aktif di Sumatera Utara berkisar antara 26,7\% sampai 59\% (Riskesdas, 2007). Kemudian Pada tahun 2013 di Sumatera Utara menunjukkan adanya penurunan angka prevalensi karies gigi pada anak yaitu sebesar 25,9\% (Riskesdas, 2013).

Masalah yang sering terjadi pada anak-anak pra sekolah khususnya pada anak yang usianya 4 tahun adalah perilaku dalam mengkonsumsi makanan atau minuman manis, namun tidak diiringi perilaku membersihkan gigi yang menyebabkan karies gigi pada anak. Sehingga orang tua sangat berperan penting dalam pendidikan anak pra sekolah, bagaimana orang tua dapat menjadi contoh yang baik, membimbing, mengarahkan, dan memotivasi dalam merawat kesehatan gigi pada anak pra sekolah (Putri,Maemunah \& Rahayu, 2017 dalam Indrianingsih dkk, 2018).

Karies gigi yang dialami anak erat kaitannya dengan peran orang tua yaitu Menurut (Worang et al, 2014 dalam Indrianingsih dkk, 2018) menyatakan peran serta dari orang tualah yang dibutuhkan anak usia pra sekolah. contoh sederhana dalam pemeliharaan kesehatan gigi pada anak adalah Orang tua harus selalu mengajarkan anak kapan saja waktu yang tepat menggosok gigi dan bagaimana cara-cara yang baik untuk menggosok gigi serta orang tua juga seharusnya mengingatkan anak setelah mengkonsumsi makanan manis sebaiknya segera berkumur dengan air putih. Sehingga dengan adanya dasar-dasar ilmu yang didapat dari orang tua, maka anak dapat mengaplikasikannya dalam kehidupan sehari-hari yang dijalaninya.

Peran orang tau memiliki hubungan yang signifikan dengan terjadinya karies gigi pada anak kelas III- VI SDN Donorejo. Masih banyak anak yang mengalami karies gigi karena kurangnya peran orang tua, sehingga orang tua diperlukan dalam pemeliharaan kesehatan anak khusunya kesehatan gigi Dari hasil penelitian Arif Rugianti (2017). Kemudian hasil penelitian Husna (2016) menunjukkan ada hubungan yang signifikan antara peranan orang tua dengan kejadian karies pada anak usia 5-6 tahun. Sehingga semakin aktif peranan orang tua maka akan semakin rendah terjadinya karies gigi pada anak usia 5-6 tahun.

Dari data pemegang program UKS di Puskesmas Sumber Mulyo Rejo Binjai Timur didapatkan bahwa tidak rutin dilaksanakan pemeriksaan gigi dan mulut karena seharusnya pemeriksaan gigi dan mulut dilakukan secara berkala yaitu sekali dalam 3 bulan. Kemudian Berdasarkan data awal yang dilakukan peneliti dari hasil observasi pada bulan maret 2019 di peroleh 30 murid TK Nurul Kamka yang mengalami karies gigi. Dari hasil observasi tersebut penyebab anak menderita karies gigi karena anak sering mengkonsumsi makanan seperti permen,es,coklat dan anak juga jarang menggosok gigi dan membersihkan mulut. 
Berdasarkan hasil wawancara yang dilakukan peneliti kepada 3 orang tua yang anaknya menderita karies gigi di TK Nurul Kamka Binjai Timur mengatakan bahwa anaknya sering mengeluh sakit gigi dikarenakan kurangnya pengawasan orang tua pada saat anak menggosok gigi.

\section{METODE PENELITIAN}

Jenis penelitian yang digunakan adalah deskriptif korelasi. Korelasi adalah suatu alat statistik, yang digunakan untuk mengidentifikasi variabel satu dengan variable yang lain dan melihat apakah ada hubungan antara keduanya. Rancangan penelitian ini menggunakan metode pendekatan cross sectional yaitu jenis penelitian yang dengan cara pendekatan, observasi atau pengumpulan data sekaligus pada suatu saat (Notoatmodjo,2017).penelitian ini bertujuan untuk mengetahui hubungan peran orang tua terhadap terjadinya karies gigi pada anak Pra Sekolah di TK Nurul Kamka Binjai Timur.

Populasi dalam penelitian ini adalah seluruh orang tua yang mempunyai anak yang mengalami karies gigi di TK Nurul Kamka Binjai Timur berdasarkan data yang diperoleh dari TK Nurul Kamka tahun 2019 sebanyak 30 orang. Teknik pengambilan sampel pada penelitian ini dengan menggunakan metode total sampling, dimana seluruh popolasi menjadi sampel yang mengalami karies gigi ini sebanyak 30 orang.

Penelitian ini menggunakan alat ukur kuesioner untuk mengukur Peran Orang Tua yang telah diuji validitas oleh Ika Prasasti, (2016) dengan nilai Cronbach Alpa yaitu sebesar 0,768. Kuesioner tersebut dinyatakan cukup reliable karena nilai a hitung >dari nilai a tabel $(0,60)$.

\section{HASIL PENELITIAN}

Adapun hasil penelitian ini dapat dilihat sebagai berikut:

Tabel 1

Distribusi Frekuensi Karakteristik Responden Di TK Nurul Kamka $(\mathbf{n}=30)$

\begin{tabular}{lcc}
\hline Karakteristik & $\boldsymbol{f}$ & $\boldsymbol{\%}$ \\
\hline Status pekerjaan orang tua & 8 & 26,7 \\
Wiraswasta & 1 & 3,3 \\
WIrausaha & 18 & 60,0 \\
Ibu rumah tangga & 3 & 10,0 \\
PNS & & \\
Jumlah Anak & 4 & 13,3 \\
1 anak & 19 & 63,3 \\
2 anak & 7 & 23,3 \\
\hline 2 anak & & \\
\hline
\end{tabular}

Berdasarkan tabel 4.1 dapat dilihat bahwa mayoritas status pekerjaan responden adalah ibu rumah tangga sebanyak 60\% dan mayoritas jumlah anak responden adalah 2 anak sebanyak $63,3 \%$.

Tabel 2

Distribusi Frekuensi Karakteristik Responden Berdasarkan Peran Orang Tua Di TK Nurul Kamka $(\mathbf{n}=30)$

\begin{tabular}{lcc}
\hline Peran orang tua & $\boldsymbol{f}$ & $\%$ \\
\hline Baik & 5 & 16,7 \\
Cukup & 15 & 50,0 \\
\hline
\end{tabular}


Berdasarkan tabel 4.2 dapat dilihat bahwa mayoritas peran orang tua responden adalah berperan cukup sebanyak $50 \%$.

Tabel 3

Distribusi Frekuensi Karakteristik Responden Berdasarkan Pemeriksaan Karies Gigi Di TK Nurul Kamka $(n=30)$

\begin{tabular}{lcc}
\hline Pemeriksaan karies gigi & $\boldsymbol{f}$ & $\boldsymbol{\%}$ \\
\hline Karies Ringan & 2 & 6,7 \\
Karies Sedang & 10 & 33,3 \\
Karies Berat & 18 & 60.0 \\
\hline
\end{tabular}

Berdasarkan tabel 4.3 dapat dilihat bahwa mayoritas pemeriksaan karies gigi anak adalah karies berat sebanyak $60 \%$.

\section{Tabel 4}

Tabulasi Silang Hubungan Peran Orang Tua Dengan Kejadian Karies Gigi Pada Anak Pra Sekolah Di TK Nurul Kamka $(n=30)$

\begin{tabular}{|c|c|c|c|c|c|c|c|c|c|}
\hline \multirow{3}{*}{$\begin{array}{c}\text { Peran } \\
\text { Orang } \\
\text { Tua }\end{array}$} & \multicolumn{6}{|c|}{ Pemeriksaan Karies Gigi } & & & \multirow{3}{*}{$P$ value } \\
\hline & \multicolumn{2}{|c|}{ Karies ringan } & \multicolumn{2}{|c|}{ Karies sedang } & \multicolumn{2}{|c|}{ Karies berat } & \multicolumn{2}{|c|}{ Total } & \\
\hline & $f$ & $\%$ & $f$ & $\%$ & $f$ & $\%$ & $f$ & $\%$ & \\
\hline Baik & 2 & 6,7 & 0 & 0 & 3 & 10 & 5 & 16,7 & \\
\hline Cukup & 0 & 0 & 7 & 23,3 & 8 & 26,7 & 15 & 50 & 0,012 \\
\hline Kurang & 0 & 0 & 3 & 10 & 7 & 23,3 & 10 & 33,3 & \\
\hline Total & 2 & 6,7 & 10 & 33,3 & 18 & 60 & 30 & 100 & \\
\hline
\end{tabular}

Berdasarkan tabel 4.4 dapat dilihat dari $16,7 \%$ yang peran orang tua baik, diantaranya didapatkan hasil pemeriksaan karies gigi ringan sebanyak 6,7\%, karies sedang $0 \%$ dan karies berat adalah $10 \%$. Sedangkan dari $50 \%$ yang peran orang tua cukup, diperoleh hasil pemeriksaan karies gigi ringan sebanyak $0 \%$, karies sedang sebanyak 23,3\% dan karies berat sebanyak $26,7 \%$. Serta dilihat dari $33,3 \%$ dengan peran orang tua kurang, diperoleh hasil pemeriksaan karies gigi ringan sebanyak $0 \%$, karies gigi sedang sebanyak $10 \%$, dan pemeriksaan karies gigi berat sebanyak $23,3 \%$.

Dari hasil uji statistik chi square di dapatkan $p$ value $=0,012(\mathrm{p}<0,050)$, menunjukkan ada hubungan peran orang tua dengan kejadian karies gigi pada anak pra sekolah di TK Nurul kamka, kecamatan Binjai Timur.

\section{PEMBAHASAN}

Peran Orang Tua

Hasil penelitian menunjukkan bahwa peran orang tua pada anak di TK Nurul Kamka binjai timur mayoritas peran orang tua responden adalah berperan cukup yaitu 50,0\%, sedangkan orang tua yang berperan kurang 33,3\%, dan orang tua yang berperan baik 16,7\%. Berdasarkan hasil jawaban dari responden pada saat pengisian kuesioner dimana mayoritas 
responden sebanyak $60 \%$ menjawab selalu pada pernyataan orang tua menyediakan sikat gigi khusus pada anak.

Penyediaan sikat gigi khusus pada anak merupakan salah satu upaya yang efektif untuk mendorong anak dalam menjaga kebersihan gigi dan mulut dengan cara menggosok gigi secara rutin dan teratur. Kebiasaan yang baik dan disiplin memelihara dan membersihkan gigi dengan cara menggosok gigi secara teratur harus sudah dimulai sejak dini sehingga generasi penerus terbiasa dengan pola hidup sehat (Kurdaningsih, 2018).

Hasil penelitian ini selaras dengan Firmansyah (2017) yang berjudul hubungan peran orang tua dengan kejadian karies gigi pada anak pra sekolah di TK Karta Rini Sleman Yogyakarta, diperoleh sebagian besar peran orang tua dikategorikan berperan cukup sebanyak $34,8 \%$ dan sebagian orang tua yang berperan kurang sebanyak $7 \%$. Dengan kejadian karies gigi karies sebanyak 56,5\% dan tidak karies sebanyak 43,5\%.

Berdasarkan hasil penelitian diperoleh bahwa pekerjaan orang tua mayoritas adalah ibu rumah tangga sebanyak 60\%. Menurut prasasti, (2016), pekerjaan anggota keluarga mempengaruhi sumber penghasilan keluarga. Orang tua terutama ibu pada umumnya memiliki peran ganda sehingga seringkali dihadapkan pada konflik antara kepentingan pekerjaan dan keberadaannya dalam keluarga.. tuntutan pekerjaan seringkali menyita waktu sehingga menghambat pemenuhan kebutuhan untuk kebersamaan dalam keluarga, merawat dan mengasuh anak, termasuk dalam malakukan pemeliharaan kesehatan gigi pada anak.

\section{Kejadian Karies Gigi}

Hasil penelitian menunjukkan bahwa kejadian karies gigi pada anak TK Nurul Kamka Binjai Timur tahun 2019, adalah mayoritas anak mengalami karies berat yaitu 60\%, sedangkan anak yang mengalami karies sedang yaitu 33,3\%, dan yang mengalami karies ringan sebanyak $6,7 \%$.

Hasil penelitian ini selaras dengan penelitian yang dilakukan oleh Rugianto, (2017) yang berjudul hubungan peran orang tua dengan kejadian karies gigi pada siswa kelas III kelas VI SDN 4 Donorojo, Kec. Sempor. Dimana jumlah sampel sebanyak 59 orang, dengan desain penelitian deskriptif korelasi dan pendekatan cross sectional. Diperoleh hasil karies gigi sebanyak $81,4 \%$ dan yang tidak karies sebanyak $(18,6 \%$.

Hasil penelitian ini, selaras dengan pernyataan Indrianingsih, dkk., (2018), bahwa anak usia prasekolah khususnya usia 4 tahun seringkali mengalami gangguan pada gigi. Timbulnya masalah kesehatan gigi dan mulut pada anak dipengaruhi oleh faktor lingkungan dan sosial. Salah satu faktor lingkungan yaitu berupa faktor perilaku atau sikap mengabaikan kebersihan gigi dan mulut. selain itu karies gigi juga bisa terbentuk karena adanya sisa-sisa makanan yang menempel pada gigi, pada akhirnya menyebabkan pengapuran gigi. dampaknya gigi menjadi keropos, berlubang bahkan patah.

Pernyataan tersebut didukung oleh madyastuti dan siswanto, (2016), bahwa anak usia pra sekolah cenderung mengespresikan emosinya dengan bebas dan terbuka, mulai senang mencoba makanan baru. Sering mengonsumsi makanan manis seperti gulali, permen, dan coklat serta minum susu. Makanan manis diketahui sebagai subtract yang disukai oleh bakteri dimana selanjutnya dapat melarutkan struktur gigi.

\section{Hubungan peran orang tua dengan kejadian karies gigi pada anak usia pra sekolah di TK Nurul Kamka Binjai Timur}

Berdasarkan hasil uji statistik menggunakan uji chi square didapatkan hasil ada hubungan peran orang tua dengan kejadian karies gigi pada anak usia pra sekolah di TK Nurul Kamka binjai timur dengan nilai $p$ value $=0,012(\mathrm{p}<0,05)$. 
Penelitian ini didukung dengan penelitian Prasarti, (2017), yang berjudul hubungan peran orang tua dalam kebersihan gigi dan mulut dengan kejadian karies gigi pada anak pra sekolah ditaman kanan-kanak TK PGRI Kelurahan Ngeserep Semarang. Dimana menggunakan desain jenis penelitian deskriptif korelasi dan menggunakan kuisioner sebagai instrument penelitian. Jumlah sampel sebanyak 125 orang tua dan anak pra sekolah, dan diperoleh hasil $\mathrm{p}$ value $0,001(\mathrm{p}<0,05)$ yang berarti ada hubungan antara peran orang tua dalam kebersihan gigi dan mulut dengan kejadian karies gigi pada anak pra sekolah ditaman kanan-kanak TK PGRI.

Penelitian lain yang mendukung adalah dilakukan oleh firmansyah (2017), yang berjudul hubungan peran orang tua dengan kejadian karies gigi pada anak pra sekolah di TK Karta Rini Godean Sleman Yogyakarta. Dimana menggunakan desain jenis penelitian kuantitatif dan metode pengambilan sampel yang digunakan adalah total sampling dengan jumlah sampel 23 orang tua dan 23 anak. Diperoleh hasil $p$ value $0,002(p<0,05)$ yang berarti ada hubungan peran orang tua dengan kejadian karies gigi pada anak pra sekolah di TK Karta Rini Godean Sleman Yogyakarta.

Kemudian Penelitian ini didukung juga dengan hasil penelitian Rugianto (2017), yang berjudul hubungan peran orang tua dengan kejadian karies gigi pada siswa kelas III-IV SDN IV Donorojo, Kecamatan Sempor yang menggunakan desain penelitian Deskriptif Korelatif dan metode pengambilan sampel yang digunakan adalah total sampling dengan jumlah 59 responden. Diperoleh hasil p value $=0,00(\mathrm{p}<0,05)$ yang berarti ada hubungan peran orang tua dengan kejadian karies gigi pada siswa kelas III-IV SDN IV Donorojo, Kecamatan Sempor

Peran orang tua sangat berpengaruh dengan kejadian karies gigi pada anak. Orang tua terutama ibu berperan sebagai pemimpin kesehatan dan pemberi asuhan kesehatan. Peran orang tua adalah sebagai pengasuh, pemberi pendidikan salah satunya adalah pendidikan kesehatan seperti mendidik anak untuk menyikat gigi, mencuci tangan sebelum dan setelah makan dan mengurangi makanan yang manis untuk mencegah karies gigi. Selanjutnya sebagai pendorong dan pengawas seperti mengawasi anak saat makan, menyikat gigi yang benar dan saat pemberian susu.

Berdasarkan hasil uji statistik menggunakan uji chi square didapatkan hasil ada hubungan peran orang tua dengan kejadian karies gigi pada anak usia pra sekolah di TK Nurul Kamka binjai timur dengan nilai $p$ value $=0,012(\mathrm{p}<0,05)$. Penelitian ini didukung dengan penelitian Prasarti, (2017), yang berjudul hubungan peran orang tua dalam kebersihan gigi dan mulut dengan kejadian karies gigi pada anak pra sekolah ditaman kanan-kanak TK PGRI Kelurahan Ngeserep Semarang. Dimana menggunakan desain jenis penelitian deskriptif korelasi dan menggunakan kuisioner sebagai instrument penelitian. Jumlah sampel sebanyak 125 orang tua dan anak pra sekolah, dan diperoleh hasil $\mathrm{p}$ value $0,001(\mathrm{p}<0,05)$ yang berarti ada hubungan antara peran orang tua dalam kebersihan gigi dan mulut dengan kejadian karies gigi pada anak pra sekolah ditaman kanan-kanak TK PGRI.

Penelitian lain yang mendukung adalah dilakukan oleh firmansyah (2017), yang berjudul hubungan peran orang tua dengan kejadian karies gigi pada anak pra sekolah di TK Karta Rini Godean Sleman Yogyakarta. Dimana menggunakan desain jenis penelitian kuantitatif dan metode pengambilan sampel yang digunakan adalah total sampling dengan jumlah sampel 23 orang tua dan 23 anak. Diperoleh hasil $p$ value $0,002(\mathrm{p}<0,05)$ yang berarti ada hubungan peran orang tua dengan kejadian karies gigi pada anak pra sekolah di TK Karta Rini Godean Sleman Yogyakarta.

Kemudian Penelitian ini didukung juga dengan hasil penelitian Rugianto (2017), yang berjudul hubungan peran orang tua dengan kejadian karies gigi pada siswa kelas III-IV SDN IV Donorojo, Kecamatan Sempor yang menggunakan desain penelitian Deskriptif Korelatif dan metode pengambilan sampel yang digunakan adalah total sampling dengan jumlah 59 responden. Diperoleh hasil $p$ value $=0,00(\mathrm{p}<0,05)$ yang berarti ada hubungan peran orang tua dengan kejadian karies gigi pada siswa kelas III-IV SDN IV Donorojo, Kecamatan Sempor 
Peran orang tua sangat berpengaruh dengan kejadian karies gigi pada anak. Orang tua terutama ibu berperan sebagai pemimpin kesehatan dan pemberi asuhan kesehatan. Peran orang tua adalah sebagai pengasuh, pemberi pendidikan salah satunya adalah pendidikan kesehatan seperti mendidik anak untuk menyikat gigi, mencuci tangan sebelum dan setelah makan dan mengurangi makanan yang manis untuk mencegah karies gigi. Selanjutnya sebagai pendorong dan pengawas seperti mengawasi anak saat makan, menyikat gigi yang benar dan saat pemberian susu.

Selanjutnya faktor lain yang menyebabkan karies gigi disebabkan karena faktor pengetahuan yang kurang tentang kesehatan gigi, sikap orang tua yang kurang tentang kesehatan gigi dan mulut juga dapat berpengaruh terhadap karies gigi. Belum semua orang tua bersikap setuju tentang mencegah karies gigi, lingkungan yang buruk, praktik/tindakan untuk menyikat gigi yang benar masih masih kurang tepat, dan pelayanan kesehatan yang buruk (Miftakun dkk, 2016).

\section{KESIMPULAN}

Ada hubungan signifikan antara peran orang tua dengan kejadian karies gigi pada anak pra sekolah di TK Nurul Kamka, Kecamatan Binjai Timur dengan nilai significancy pada hasil menunjukkan $(\mathrm{p}=0,012<0,05)$.

\section{REFERENSI}

Amaliya, \& Dkk. (2014). Prosiding temu ilmiah BANDUNG DENTISTRY XI. bandung: lembaga studi kesehatan Indonesia (LSKI).

Angela, A. (2005a). Pencegahan Primer Pada Anak Yang berisiko Karies Tinggi. Jurnal Maj. Ked. Gigi.

Angela, A. (2005b). Pencegahan Primer pada Anak yang Berisiko Karies Tinggi. Maj. Ked. Gigi. (Dent. J.), 38, 130-134.

Eddy, F. N. E., \& Mutiara, H. (2015). Peranan Ibu dalam Pemeliharaan Kesehatan Gigi Anak dengan Status Karies Anak Usia Sekolah Dasar. Medical Journal of Lampung University, 4(8), 1-6. Retrieved from http://juke.kedokteran.unila.ac.id/index.php/majority/article/view/1464

Firmansyah, W. C. (2017). Hubungan Peran Orang Tua Dengan Kejadian Karies Gigi Pada Anak Prasekolah Di Tk Karta Rini Sleman Yogyakarta. (December).

Friedman, M. M. (2013). Buku Ajar Keperawatan Keluarga. Jakarta: Buku Kedokteran EGC.

Herdiyanti Nonong, Y. (2014). Gigi Sehat Sejak Dalam Kandungan Sampai Usia Tua. Retrieved from http://pustaka.unpad.ac.id/wp-content/uploads/2015/04/019-Gigi-SehatSejak-Dalam-Kandungan-Sampai-Usia-Tua.pdf

Indrianingsih, N., Prasetyo, Y. B., \& Kurnia, A. D. (2018). Family Social Support and Behavior of Children with Caries in Doing Dental and Oral Care. Jurnal Keperawatan, 9(2), 119. https://doi.org/10.22219/jk.v9i2.5480

Katli. (2018a). Faktor-faktor Kejadian Karies Gigi Pada Balita Di Wilayah Kerja Puskesmas Betungan Kota Bengkulu. Journal Of Nursing And Public Health, 6(1).

Katli. (2018b). Faktor-Faktor Kejadian Karies Gigi Pada Balita Di Wilayah Kerja Puskesmas Betungan Kota Bengkulu. Journal of Nursing and Public Health, 6(1), 46-52.

Kurdaningsih, S. V. (2018). Hubungan Kebiasaan Menggosok Gigi Dengan Timbulnya Karies Gigi Pada Anak Usia Sekolah Di Sdn 135 Palembang Tahun 2017. Jurnal 'Aisyiyah Medika, 1(1), 8-14.

Kyle, T., \& Carman, S. (2017). Buku Ajar Keperawatan Pediatri. Jakarta: Buku Kedokteran 
EGC.

Notoatmodjo, S. (2017). Metodologi Penelitian Kesehatan. jakarta: Rineka Cipta.

Oktiawati, A., \& Dkk. (2017). Teori Dan Konsep Keperawatan Pediatrik. jakarta: CV. Trans Info Media.

Orang, P., Dan, T. U. A., \& Anak, P. (2012). Peranan orang tua dan perilaku anak dalam menyikat gigi dengan kejadian karies anak. 221-227.

Prasasti, I. (2016). Gigi Dan Mulut Dengan Kejadian Karies Gigi Pada Anak Pra Sekolah Di Taman Kanak-Kanak.

Riskesdas. (2018a). Laporan Nasional Riskesdas 2018/ Badan Penelitian dan Pengembangan Kesehatan. In Lembaga Penerbit Badan Penelitian dan Pengembangan Kesehatan (LPB (Vol. 3).

Riskesdas. (2018b).

Rugianto, A. (2017). Hubungan Peran Orang Tua Dengan Kejadian Karies Gigi Pada Siswa Kelas Iii - Vi Sdn Iv Donorojo Kecamatan Sempor. (December).

Hidayat, A. A. A. (2009). Metode penelitian keperawatan dan teknik analisa data, Jakarta: Salemba Medika

Tarigan, R. (2017). Karies Gigi. Jakarta: Buku Kedokteran EGC.

Yundali, S., Hongini, \& Mac, A. (2017). karies gigi. In Kesehatan Gigi \& Mulut (pp. 55-74). bandung: Pustaka Reka Cipta.

Z, I. I., \& Intan, S. A. (2017). karies gigi. In Penyakit Gigi, Mulut dan THT (pp. 18-25). yogyakarta: Nuha Medika. 